The Bonds of Womanhood 



\section{The Bonds of Womanhood}

"Woman's Sphere" in New England, 1780-1835

Second Edition

With a new Preface

Nancy F. Cott

Yale University Press New Haven and London 
First published in 1977 by Yale University Press.

Second edition published in 1997 with a new preface.

Copyright (C) 1977 by Yale University.

Preface to second edition (C) 1997 by Yale University.

All rights reserved.

This book may not be reproduced, in whole or in part, including illustrations, in any form (beyond that copying permitted by Sections 107 and 108 of the U.S. Copyright Law and except by reviewers for the public press), without written permission from the publishers.

Library of Congress Cataloging in Publication Number 97-60429 ISBN 0-300-07298-8

A catalogue record for this book is available from the British Library.

The paper in this book meets the guidelines for permanence and durability of the Committee on Production Guidelines for Book Longevity of the Council on Library Resources.

$\begin{array}{lllllll}10 & 9 & 8 & 7 & 6 & 5 & 4\end{array}$ 
To my parents

Estelle Hollander Falik

and

Max E. Falik 
